\title{
Taphonomy and Paleoecology of Fossil Insect Assemblages from Old Crow River (CRH-15) Northern Yukon Territory, Canada
}

\author{
Taphonomie et paléoécologie d'associations d'insectes fossiles \\ au site d'Old Crow River (CRH-15), nord du Yukon, Canada \\ Taphonomie und Paleoökologie in fossilen Insekten \\ Zusammensetzungen vom old Crow Fluss (Lokalität CRH-15), \\ nördliches Yukon Territory, Kanada
}

\author{
Richard E. Morlan et John V. Matthews
}

Volume 37, numéro 2, 1983

URI : https://id.erudit.org/iderudit/032511ar

DOI : https://doi.org/10.7202/032511ar

\section{Aller au sommaire du numéro}

Éditeur(s)

Les Presses de l'Université de Montréal

ISSN

0705-7199 (imprimé)

1492-143X (numérique)

Découvrir la revue

Citer cet article

Morlan, R. E. \& Matthews, J. V. (1983). Taphonomy and Paleoecology of Fossil Insect Assemblages from Old Crow River (CRH-15) Northern Yukon Territory, Canada. Géographie physique et Quaternaire, 37(2), 147-157.

https://doi.org/10.7202/032511ar

\section{Résumé de l'article}

Le message paléoenvironnemental transmis par toute association de fossiles est presque toujours plus ou moins dénaturé par des facteurs liés à la taphonomie et à la préservation. Le rapport présente certaines catégories de facteurs qui influent sur la composition des associations de coléoptères fossiles. Les données brutes sont tirées de huit échantillons provenant d'un seul emplacement dans le nord du Yukon. Ces échantillons représentent divers types de sédiments encaissants. Pour chaque association, on a noté l'état de préservation des fossiles, compté le nombre de parties anatomiques (pronota, têtes, élytres) par taxon et le nombre d'échantillons articulés ou partiellement articulés, et trié les fossiles selon des groupes écologiques prédéterminés. Les données ont été étudiées statistiquement, puis comparées aux conclusions paléoenvironnementales tirées de l'étude de la répartition actuelle des taxons dans chaque association. Le contenu des associations d'insectes varie en fonction du type de sédiment encaissant. Les insectes fossiles dans les sédiments autochtones fournissent des données fiables sur l'environnement local. Les sédiments allochtones comme les alluvions devraient contenir des fossiles qui donneraient une image intégrée de l'environnement régional; toutefois, au Yukon, ces échantillons sont gravement surreprésentés par le Lepidophorus lineaticollis. Les écarts dans la représentation des éléments anatomiques particuliers de L. lineaticollis dans les divers échantillons avertissent le chercheur de l'existence d'autres facteurs taphonomiques plus subtils qui pourraient modifier le contenu des associations d'insectes fossiles dans le Nord. 


\title{
TAPHONOMY AND PALEOECOLOGY OF FOSSIL INSECT ASSEMBLAGES FROM OLD CROW RIVER (CRH-15) NORTHERN YUKON TERRITORY, CANADA
}

\author{
Richard E. MORLAN and John V. MATTHEWS, Jr., respectively, Archaeological Survey of Canada, National Museum \\ of Man, Ottawa, Ontario K1A 0M8, and Terrain Sciences Division, Geological Survey of Canada, 601 Booth Street, \\ Ottawa, Ontario K1A 0E8.
}

\begin{abstract}
The paleoenvironmental message delivered by any fossil assemblage is nearly always filtered to some degree by taphonomic and preservational biases. This paper discusses some of the types of biases that affect the composition of fossil Coleoptera (beetles) assemblages. Eight samples from a single site in the northern Yukon provide the raw data for the analysis. They represent different types of host sediments - ranging from autochthonous peats to organic rich alluvial sands. For each assemblage the authors noted the state of preservation of the fossils, counted the individual anatomical parts (pronota, heads, elytra) referred to each taxon and the number of articulated or partially articulated specimens, and sorted the fossils on the basis of predefined ecological groups. The resulting data were then examined statistically, and compared with paleoenvironmental conclusions derived by examination of the present distribution of the taxa in each assemblage. The content of the insect assemblages varies with the type of host sediment. Insect fossils from autochthonous sediments deliver a reliable local environmental signal. Allochthonous sediments, such as alluvium, might be expected to contain fossils that provide an integrated picture of the regional environment, but in the Yukon such samples are seriously overrepresented by Lepidophorus lineaticollis, a weevil that lives on or near sandy floodplains. Deviations in the representation of particular anatomical elements of $L$. lineaticollis from one sample to another warn of other more subtle taphonomic biases that may also skew the content of northern fossil insect assemblages.
\end{abstract}

RÉSUME Taphonomie et paléoécologie d'associations d'insectes fossiles au site d'Old Crow River (CRH-15), nord du Yukon, Canada. Le message paléoenvironnemental transmis par toute association de fossiles est presque toujours plus ou moins dénaturé par des facteurs liés à la taphonomie et à la préservation. Le rapport présente certaines catégories de facteurs qui influent sur la composition des associations de coléoptères fossiles. Les données brutes sont tirées de huit échantillons provenant d'un seul emplacement dans le nord du Yukon. Ces échantillons représentent divers types de sédiments encaissants. Pour chaque association, on a noté l'état de préservation des fossiles, compté le nombre de parties anatomiques (pronota, têtes, élytres) par taxon et le nombre d'échantillons articulés ou partiellement articulés, et trié les fossiles selon des groupes écologiques prédéterminés. Les données ont été étudiées statistiquement, puis comparées aux conclusions paléoenvironnementales tirées de l'étude de la répartition actuelle des taxons dans chaque association. Le contenu des associations d'insectes varie en fonction du type de sédiment encaissant. Les insectes fossiles dans les sédiments autochtones fournissent des données fiables sur l'environnement local. Les sédiments allochtones comme les alluvions devraient contenir des fossiles qui donneraient une image intégrée de l'environnement régional; toutefois, au Yukon, ces échantillons sont gravement surreprésentés par le Lepidophorus lineaticollis. Les écarts dans la représentation des éléments anatomiques particuliers de $L$. lineaticollis dans les divers échantillons avertissent le chercheur de l'existence d'autres facteurs taphonomiques plus subtils qui pourraient modifier le contenu des associations d'insectes fossiles dans le Nord.
ZUSAMMENFASSUNG Taphonomie und Paleoökologie in fossilen Insekten Zusammensetzungen vom old Crow Fluss (Lokalität CRH - 15), nördliches Yukon Territory, Kanada.Die paleo-ökologische Botschaft, die uns durch jede fossile Zusammensetzung gegeben wird, ist fast immer bis zu einem gewissen Grade durch taphonomische und Preservierungs Tendenzen gefiltert. Dieser Artikel behandelt einige der typischen Verformungen welche die Komposition von fossilen Coleopters (Käfer) Zusammensetzungen angehen. Acht Proben von einem einzigen Forschungssitz im nördlichen Yukon, ergeben die Daten für die Analyse. Sie repräsentieren verschiedene Typen von Wirts-Sedimenten. Für jede Zusammensetzung haben die Autoren den Erhaltungszustand der Fossile vermerkt, die individuellen anatomischen Teile gezählt (Pronota, Köpfe, Elytra) in Bezug auf jedes Taxon und die Zahl der artikulierten oder teilweise artikulierten Specimen, und haben die Fossile nach predefinierten ökologischen Gruppen sortiert. Der Inhalt der Insekten Zusammensetzungen verändert sich je nach dem Typ des Wirts-Sedimentes. Insektenfossile aus einheimischen Sedimenten ergeben ein sicheres, örtliches ökologisches Signal. Vom Inhalt der allochtonen Sedimente, wie Alluvium, möge man einen Gehalt an Fossilen die ein Gesamtbild der regionalen Umgebung ergibt, erwarten aber im Yukon sind solche Proben sehr beeinflusst durch die Gegenwart von Lepidophorus lineaticollis. Abweichungen in der Vertretung von speziellen anatomischen Elementen von L. lineaticollis von einer Probe zur anderen, warnen vor anderen, mehr subtilen taphonomischen Tendenzen, die auch den Inhalt von nördlichen Fossil Insekt Zusammensetzungen beeinflussen können. 


\section{INTRODUCTION}

For the past six years a group of workers from the Geological Survey of Canada, University of Alberta, and the National Museums of Canada, has co-operated in the Yukon Refugium Project, a geological, paleoecological and archaeological study of the northern Yukon part of the Beringian refugium. Summary papers describing the general and detailed findings at a number of sites are now published or in preparation (HUGHES et al., 1981). The Old Crow Basin has been the focus of most of this research, and one site in particular, $\mathrm{CRH}-15\left(67^{\circ} 51.5^{\prime} \mathrm{N} ; 139^{\circ} 48^{\prime} \mathrm{W}\right.$.), also known informally as Old Crow River Location 15, has received more detailed study than the rest. The site is located on Old Crow River approximately $1 \mathrm{~km}$ above the mouth of Johnson Creek (Fig. 1) and is of particular significance because it was one of those discussed in LICHTI-FEDEROVICH's (1973) pioneering pollen study of the exposures in the region (and is now the subject of a much more detailed pollen study by Keary Walde, University of Alberta). The site contains a good exposure of the Old Crow tephra, and it has yielded several samples of vertebrate fossils from different stratigraphic contexts (MORLAN, 1980: Chapter 6).

Eight macrofossil samples from $\mathrm{CRH}-15$ have received preliminary analysis for their content of fossil insects. This paper deals with the taphonomic and paleoecological implications of the fossils. It also itlustrates the application of a method of grouping fossils from insect assemblages in order to facilitate comparisons (see MATTHEWS, 1983). The research is of a preliminary character, because not all of the insect specimens have been exhaustively studied; nevertheless, the available data point to conclusions concerning the reliability of fossil insects for documenting paleoenvironments. These data also suggest the existence of taphonomic biases, a problem not previously addressed in the burgeoning literature on Pleistocene insect fossils.

\section{STRATIGRAPHY AND SAMPLE PROVENANCE}

Like many of the sections in the Old Crow Basin, $\mathrm{CRH}-15$ contains lacustrine units separated by a thick alluvial unit (MORLAN and MATTHEWS, 1978). The lower lacustrine unit, at river level, was originally thought to have formed in late Pleistocene time during one of the periods when glaciers blocked eastward drainage through the Richardson Mountains. This blockage caused lowlands west of the mountains, such as Old Crow Basin, to be flooded with diverted meltwater (HUGHES, 1972). The age of the lower lake unit in Old Crow Basin is not known, but recent evidence suggests that it is older than early Wisconsinan (MORLAN, n.d.a.: Table 4). The upper lacustrine unit caps most exposures in the Old Crow and Bluefish Basins. Its clays and silts were deposited in a glacial

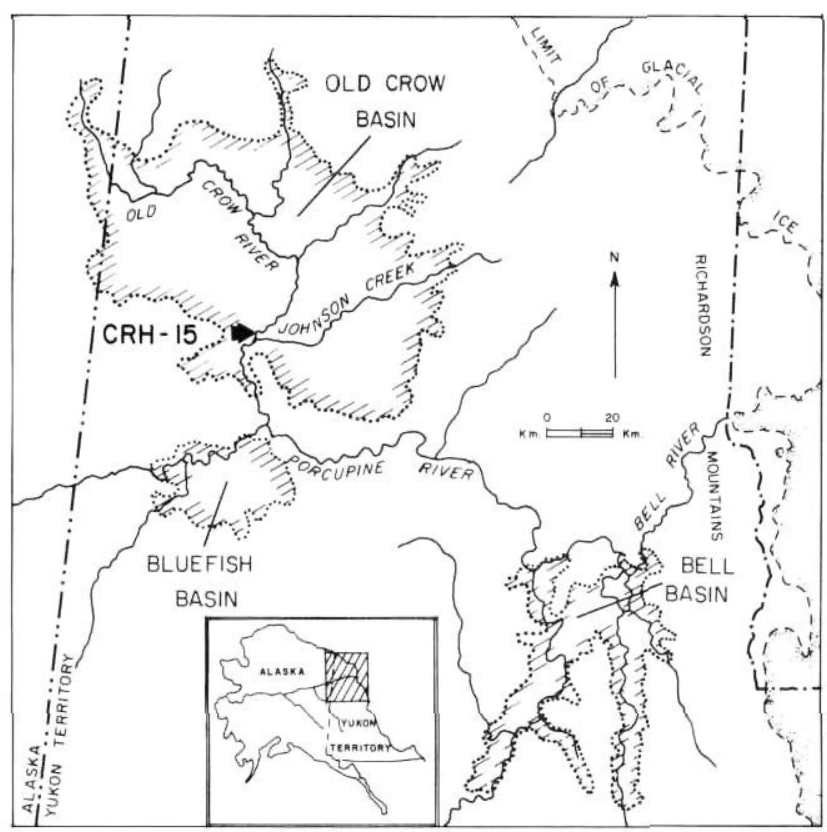

FIGURE 1. Map of the northern Yukon portion of eastern Beringia showing the location of $\mathrm{CRH}-15$ and some of the features related to late Pleistocene drainage history (modified after HUGHES, 1972: map 1319A; see also HUGHES et al., 1981).

Carte de l'est de la Béringie, au nord du Yukon, montrant la localisation du site $\mathrm{CRH}-15$ ainsi que certains éléments reliés à l'évolution du drainage au cours du Pléistocène supérieur (modifié d'après HUGHES, 1972: carte $n^{\circ} 1319 A$; voir aussi HUGHES et al., 1981).

meltwater lake that occupied the basin between approximately 25000 and 12000 years ago.

At $\mathrm{CRH}-15$, the alluvial unit consists of approximately $22 \mathrm{~m}$ of organic-rich sand, silt and clayey sediments. The Old Crow tephra, a valuable marker horizon for the entire Alaska/Yukon region (WESTGATE et al., 1983), is found in the upper few meters of the unit. A prominent disconformity that can be traced along the entire length of the section occurs about one meter above the tephra (4-5 $\mathrm{m}$ below the base of the upper lacustrine unit). The disconformity is found at other sections in the basin and apparently represents a short but intense period of climatic warming during the early part of Isotope Stage 3 or late in Isotope stage 5. At $\mathrm{CRH}-15$, the disconformity (informally known as Disconformity A) is generally expressed as a true angular unconformity truncating cryoturbated horizons and ice-wedge pseudomorphs, and locally as a surface peat with an underlying gleysol. At one station, the transition from autochthonous surface peat to an erosional contact is abrupt.

Of the many samples that have been collected at $\mathrm{CRH}-15$ during our study of the section, eight are discussed in this paper. In addition to insect fossils, some of these samples have yielded fossils of large and small mammals, birds and fishes, conifer cones, seeds, mos- 
ses, gastropods, pelecypods, and ostracods (CUMBAA et al., 1981; JANSSENS, 1981; BOBROWSKY, 1982; MORLAN, n.d.b.). Sample 78-91 comes from yellowbrown sand about $18 \mathrm{~m}$ below Disconformity $A$ and immediately above the clay of the lower lacustrine unit at Station 11 (MORLAN, 1980: Chapters 2, 6, Fig. 6.1). Seven other samples are associated with the disconformity at Station 2, 30-50 cm above Old Crow tephra. Sample 78-63 represents a former forest floor, with criss-crossed spruce twigs, some with needles still attached, and an underlying gleysol. Within a lateral distance of a few meters the soil and surface debris are cut out along an erosional contact and replaced by light brown cross-bedded silt and sand resting on bluegrey silty clay. The water-washed rootlet mat of the forest floor is visible at the spot where this lateral change occurs, and "peat balls" apparently derived from it occur nearby at the erosional contact. Three such "peat balls" from the same station and horizon are represented by samples $78-48,78-49$, and $78-50$. Zones of allochthonous organic detritus (sample 78-64) also occur on the disconformity. A large scour feature at the contact, approximately $10 \mathrm{~m}$ laterally from the forest bed, contains several large pieces of autochthonous peat, one of which is the source of sample 78-1. Sample 77-51 comes from the less organic cross-bedded sand and silt just above the disconformity at Station 2 .

\section{METHODS}

The insect assemblages were collected as bulk samples in the field, then sieved later in the laboratory with $80 \mathrm{mesh} /$ inch $(0.180 \mathrm{~mm})$ sieves (Table I). All material remaining on the sieve was soaked for three days in kerosene and then floated in warm water (cf. COOPE, 1979). Fossils were picked from the float fraction using a low power microscope. Small subsamples of the sink fraction were examined in order to assess the reliability of the kerosene-floatation method. In no case were significant numbers or particular kinds of insect fragments found in the sink fraction; therefore, we conclude that the kerosene-float procedure has not biased the fossil insect assemblages.

All identifiable parts of insects were picked from the float fraction of the processed samples. Practically all of the fossils come from beetles (Coleoptera); hence the following discussion centres on coleopteran anatomy. The most common fossils were heads, pronota and elytra (whole or halves) or fragments thereof. Identifications were made by comparing the fragments with identified specimens in the authors' respective reference collections of Alaskan and Yukon Coleoptera. In the Tables a "?" indicates that the preserved fragments were too few, too incomplete or too poorly preserved to allow a positive identification. A "cf" implies that preservation is probably adequate for identification, but that the fossil does not match any known species. A "cf"-designated fossil could represent an unknown variant of an extant species, an undescribed taxon, or an extinct form. The latter possibility is unlikely considering the well established longevity of northern coleopteran species (COOPE, 1978; MATTHEWS, 1980), but it should not be ruled out summarily.

Since we planned a quantitative treatment, tabulation criteria were established in order to insure totals suitable for estimating minimum numbers of individuals (MNI). Elytra were designated as left or right and further divided into the following classes: "intact", "base only", "apex only", or "fragment." Pronota were recorded as "intact," "left half," "right half," "basal half," or "distal half." The highest count of either left or right elytra (and elytral fragments) was added to the count of whole (fused) elytra to obtain an MNI estimate, and if this figure was larger than the weighted count of pronota (including pronotal fragments) or heads of the same taxon (often it was), it became the final estimate of MNI for the taxon.

We would have preferred to avoid the use of $\mathrm{MNI}$ counts by employing a true estimate of population size (e.g., FIELLER and TURNER, 1982), but such estimates require an objective means of pairing a left and a right element that might represent the same individual. Measurements are usually employed for this purpose, but measurements of elytra are often impractical due to post-mortem deformation and fragmentation. Therefore, we have used $\mathrm{MNI}$ counts with the reservations discussed below (see also TURNER, 1980).

One complicating factor in deriving $\mathrm{MNI}$ estimates from the assemblages listed in Table I is that the level of identification varies greatly. Furthermore, the most abundant kind of fragment is not always the one that allows the most precise identification, and a given anatomical element is not equally diagnostic for all taxa. Pronota, for example, must be used to obtain species names for some carabids, whereas with others the head or the elytron offers the best characters.

A few specimens are identified to the species level, but many could only be assigned to the family, genus, or subgenus. If $\mathrm{MNI}$ estimates were based only on specifically determined fossils, the totals would be too small to be statistically meaningful. The problem can be circumvented by careful consideration of numerical implications of the less precisely identified fossils. For example, in sample 77-51 five pronota are identified as belonging to the species Helophorus splendidus. In addition there are 12 Helophorus heads in the sample. Since $H$. splendidus cannot be identified by head fragments, and all of the heads were of the type possessed by $H$. splendidus and its close relatives, five of the heads in the group of twelve could easily have been from the same individuals as the five $H$. splendidus pronota. The count for Helophorus would have been inflated if all heads and pronota were summed to obtain the total MNI. Instead we have counted only seven of the Helophorus heads, to give a total of 12 individuals, of which 5 are known to be $\mathrm{H}$. splendidus. If in the future it 
TABLE ।

Distribution of fossil insects in samples from Old Crow River Loc. 15, northern Yukon Territory *

\begin{tabular}{|c|c|c|c|c|c|c|c|c|c|}
\hline Samples: & $77-51$ & $78-64$ & $78-91$ & $78-1$ & $78-48$ & $78-49$ & $78-50$ & $78-63$ & Totals \\
\hline $\begin{array}{l}\text { INSECTA, undet. } \\
\text { Homoptera }\end{array}$ & & & + & & & & & & \\
\hline Cicadellidae & + & + & + & & & + & + & & \\
\hline Psyllidae & + & & & & & & & & \\
\hline ? Coleoptera, undet. & $1(0)$ & $1(0)$ & $14(0)$ & $1(0)$ & $2(0)$ & 0 & $1(0)$ & 0 & $20(0)$ \\
\hline ? Carabidae, undet. & $5(0)$ & $3(0)$ & $50(0)$ & 0 & 0 & 0 & 0 & 0 & $58(0)$ \\
\hline ?2 Carabus sp. & 0 & 0 & $1(1)$ & 0 & 0 & 0 & 0 & 0 & $1(1)$ \\
\hline 2 Opisthius richardsoni Kby. & 0 & 0 & $1(1)$ & 0 & 0 & 0 & 0 & 0 & $1(1)$ \\
\hline 2 Notiophilus sp. & 0 & 0 & $3(2)$ & 0 & 0 & 0 & 0 & 0 & $3(2)$ \\
\hline 1 Diacheila sp. & $1(1)$ & 0 & 0 & 0 & 0 & 0 & 0 & 0 & $1(1)$ \\
\hline 1D. polita Fald. & 0 & 0 & $16(4)$ & 0 & 0 & 0 & 0 & 0 & $16(4)$ \\
\hline 3 Blethisa sp. & 0 & 0 & $1(1)$ & 0 & 0 & 0 & 0 & 0 & $1(1)$ \\
\hline 2 Elaphrus sp. & 0 & $1(1)$ & $6(2)$ & 0 & 0 & 0 & $1(1)$ & 0 & $8(4)$ \\
\hline 1 Dyschirius sp. & 0 & 0 & $2(1)$ & 0 & 0 & 0 & 0 & 0 & $2(1)$ \\
\hline 1D. nigricornis Mtsch. & $1(1)$ & 0 & 0 & 0 & 0 & 0 & 0 & 0 & $1(1)$ \\
\hline 1 Patrobus sp. & 0 & 0 & $1(1)$ & 0 & 0 & 0 & 0 & 0 & $1(1)$ \\
\hline $1 P$. septentrionis Dej. & 0 & 0 & $1(1)$ & 0 & 0 & 0 & 0 & 0 & $1(1)$ \\
\hline ?2 Bembidion sp. & $2(2)$ & $1(1)$ & $15(2)$ & 0 & 0 & 0 & 0 & 0 & $18(5)$ \\
\hline 2 B. arcticus grp. & 0 & 0 & $5(4)$ & 0 & 0 & 0 & 0 & 0 & $5(4)$ \\
\hline $2 B$. umiatense Lth. & 0 & 0 & $7(4)$ & 0 & 0 & 0 & 0 & 0 & $7(4)$ \\
\hline 1B. morulum Lec. & 0 & 0 & $1(1)$ & 0 & 0 & 0 & 0 & 0 & $1(1)$ \\
\hline 1 B. ?morulum Lec. & 0 & 0 & $1(1)$ & 0 & 0 & 0 & 0 & 0 & $1(1)$ \\
\hline $2 B$. acutifrons type & 0 & 0 & $1(1)$ & 0 & 0 & 0 & 0 & 0 & $1(1)$ \\
\hline ?1 Pterostichus sp. & 0 & $7(3)$ & $14(0)$ & 0 & 0 & 0 & 0 & 0 & $21(3)$ \\
\hline 1P. cf. P. nearcticus Lth. & 0 & 0 & $4(2)$ & 0 & 0 & 0 & 0 & 0 & $4(2)$ \\
\hline $1 P$. (Cryobius) sp. & $25(16)$ & $18(10)$ & $227(107)$ & $7(3)$ & 0 & $2(1)$ & 0 & 0 & $279(137)$ \\
\hline 1P. ?(Cryobius) & 0 & 0 & $6(0)$ & 0 & 0 & 0 & 0 & 0 & $6(0)$ \\
\hline 1P. (C.) kotzebuei Ball & 0 & 0 & $1(1)$ & 0 & 0 & 0 & 0 & 0 & $1(1)$ \\
\hline 1P. (C.) tareumiut Ball & $2(2)$ & 0 & $1(1)$ & 0 & 0 & 0 & 0 & 0 & $3(3)$ \\
\hline 1P. (C.) ?hudsonicus Lec. & 0 & 0 & $2(2)$ & 0 & 0 & 0 & 0 & 0 & $2(2)$ \\
\hline 1P. cf. P. (C.) pinguedineus Eschz. & 0 & $2(2)$ & 0 & 0 & 0 & 0 & 0 & 0 & $2(2)$ \\
\hline 1P. (C.) ventricosus Eschz. & $1(1)$ & 0 & $5(5)$ & $1(1)$ & 0 & 0 & 0 & 0 & $7(7)$ \\
\hline 1P. (C.) caribou Ball & 0 & 0 & 0 & 0 & 0 & 0 & 0 & $1(1)$ & $1(1)$ \\
\hline $1 P$. (C.) brevicornis Kby. & $2(2)$ & $1(1)$ & $6(6)$ & 0 & 0 & 0 & 0 & 0 & $9(9)$ \\
\hline 1P. (C.) brevicornis type & 0 & $4(3)$ & $57(27)$ & 0 & 0 & 0 & 0 & 0 & $61(30)$ \\
\hline $1 P$. vermiculosus Men. & 0 & 0 & $1(1)$ & 0 & 0 & 0 & 0 & 0 & $1(1)$ \\
\hline $2 P$. sublaevis Sahlb. & 0 & $1(1)$ & $2(2)$ & 0 & 0 & 0 & 0 & 0 & $3(3)$ \\
\hline 1P. haematopus Dej. & $1(1)$ & $1(1)$ & $1(1)$ & 0 & 0 & 0 & 0 & 0 & $3(3)$ \\
\hline 1P. ?haematopus Dej. & $3(2)$ & 0 & $2(2)$ & 0 & 0 & 0 & 0 & 0 & $5(4)$ \\
\hline 2 Amara sp. & $3(0)$ & $5(3)$ & $1(0)$ & 0 & 0 & 0 & 0 & 0 & $9(3)$ \\
\hline 2 Amara? & 0 & $4(0)$ & $3(0)$ & 0 & 0 & 0 & $1(1)$ & 0 & $8(1)$ \\
\hline $2 A$. (Curtonotus) sp. & $1(0)$ & 0 & $9(4)$ & 0 & 0 & $1(1)$ & 0 & 0 & $11(5)$ \\
\hline 2A. ?(Curtonotus) & 0 & 0 & $4(0)$ & 0 & 0 & 0 & 0 & 0 & $4(0)$ \\
\hline $2 A$. (C.) alpina Payk. & $7(7)$ & $6(6)$ & $6(6)$ & 0 & 0 & 0 & 0 & 0 & $19(19)$ \\
\hline 2A. (C.) ?alpina Payk. & 0 & 0 & $1(1)$ & 0 & 0 & 0 & 0 & 0 & $1(1)$ \\
\hline 2 A. (C.) bokori Cski. & $2(2)$ & 0 & 0 & 0 & 0 & 0 & 0 & 0 & $2(2)$ \\
\hline $2 A$. (s.st.) sp. & 0 & 0 & $10(5)$ & 0 & 0 & 0 & 0 & 0 & $10(5)$ \\
\hline 2 Harpalus sp. & 0 & $1(0)$ & $2(1)$ & 0 & 0 & 0 & 0 & 0 & $3(1)$ \\
\hline ?2 Harpalus? & 0 & 0 & $1(0)$ & 0 & 0 & 0 & 0 & 0 & $1(0)$ \\
\hline $2 \mathrm{H}$. amputatus Say & $1(1)$ & 0 & 0 & 0 & 0 & 0 & 0 & 0 & $1(1)$ \\
\hline $2 \mathrm{H}$. cf. $\mathrm{H}$. alaskensis Lth. & 0 & $1(1)$ & 0 & 0 & 0 & 0 & 0 & 0 & $1(1)$ \\
\hline 1 Trichocellus mannerheimi Sahlb. & $1(1)$ & 0 & $4(2)$ & 0 & 0 & 0 & 0 & 0 & $5(3)$ \\
\hline 3 Haliplidae, undet. & 0 & 0 & $1(1)$ & 0 & 0 & 0 & 0 & 0 & $1(1)$ \\
\hline 3 Dytiscidae, undet. & $3(0)$ & $3(1)$ & $2(0)$ & $2(1)$ & $7(4)$ & $10(1)$ & $7(0)$ & $4(1)$ & $38(8)$ \\
\hline 3 Hydroporus sp. & $3(3)$ & $3(1)$ & $1(1)$ & 0 & $5(2)$ & $8(4)$ & $5(3)$ & $2(1)$ & $27(15)$ \\
\hline $3 H$. (Oreodytes) sp. & 0 & 0 & $2(0)$ & 0 & 0 & 0 & 0 & 0 & $2(0)$ \\
\hline 3 cf. Agabus sp. & 0 & 0 & 0 & 0 & 0 & 0 & $1(1)$ & 0 & $1(1)$ \\
\hline 3 Agabus or llybius sp. & 0 & 0 & $18(3)$ & 0 & 0 & 0 & 0 & 0 & $18(3)$ \\
\hline
\end{tabular}




\begin{tabular}{|c|c|c|c|c|c|c|c|c|c|}
\hline Samples: & $77-51$ & $78-64$ & $78-91$ & $78-1$ & $78-48$ & $78-49$ & $78-50$ & $78-63$ & Totals \\
\hline 3 cf. Neoscutopterus sp. & $1(1)$ & 0 & 0 & 0 & 0 & 0 & 0 & 0 & $1(1)$ \\
\hline 3 Colymbetes sp. & $1(1)$ & 0 & 0 & $1(1)$ & 0 & $1(1)$ & 0 & 0 & $3(3)$ \\
\hline 3 Gyrinidae, undet. & 0 & 0 & $3(1)$ & 0 & 0 & 0 & 0 & 0 & $3(1)$ \\
\hline 3 ?Gyrinidae, undet. & 0 & 0 & $2(0)$ & 0 & 0 & 0 & 0 & 0 & $2(0)$ \\
\hline 3 Hydrophilidae, undet. & 0 & 0 & $4(0)$ & $2(0)$ & 0 & 0 & 0 & 0 & $6(0)$ \\
\hline 3 Helophorus sp. & $17(7)$ & $12(6)$ & $2(2)$ & 0 & $7(0)$ & $39(12)$ & $23(7)$ & $6(2)$ & $106(36)$ \\
\hline $3 \mathrm{H}$. splendidus type & $5(5)$ & 0 & 0 & 0 & $3(3)$ & 0 & $1(1)$ & $2(2)$ & $11(11)$ \\
\hline 3 Hydrobius sp. & 0 & 0 & 0 & $4(2)$ & 0 & 0 & 0 & 0 & $4(2)$ \\
\hline 3 Ochthebius sp. & 0 & 0 & 0 & $26(8)$ & 0 & 0 & 0 & 0 & $26(8)$ \\
\hline 3 Ochthebius? & 0 & 0 & $1(1)$ & 0 & $1(1)$ & 0 & 0 & 0 & $2(2)$ \\
\hline ? Staphylinidae, undet. & $1(0)$ & 0 & $3(1)$ & $3(0)$ & 0 & $1(0)$ & 0 & 0 & $8(1)$ \\
\hline 2 Bledius sp. & 0 & 0 & $4(2)$ & 0 & 0 & 0 & 0 & 0 & $4(2)$ \\
\hline 2 Bledius? & 0 & 0 & $2(2)$ & 0 & 0 & 0 & 0 & 0 & $2(2)$ \\
\hline $1^{\star \star}$ Eucnecosum sp. & 0 & 0 & $3(3)$ & 0 & 0 & 0 & 0 & 0 & $3(3)$ \\
\hline $1^{* \star E u c n e c o s u m ? ~}$ & 0 & 0 & $6(0)$ & 0 & 0 & 0 & 0 & 0 & $6(0)$ \\
\hline 3 Olophrum sp. & 0 & 0 & $4(3)$ & 0 & 0 & $7(0)$ & $2(0)$ & 0 & $3(3)$ \\
\hline 30. latum type & 0 & $1(1)$ & 0 & 0 & $1(1)$ & $6(6)$ & $1(1)$ & 0 & $9(9)$ \\
\hline 2 Micralymma sp. & $21(12)$ & $3(2)$ & $2(1)$ & $5(2)$ & $1(1)$ & $4(2)$ & $4(3)$ & 0 & $40(23)$ \\
\hline 3 Stenus sp. & $1(1)$ & 0 & $10(3)$ & $8(3)$ & $28(8)$ & $54(16)$ & $51(18)$ & $31(11)$ & $183(60)$ \\
\hline 3 Stenus? & 0 & 0 & $1(0)$ & 0 & 0 & 0 & 0 & 0 & $1(0)$ \\
\hline 3 Euaesthetus sp. & 0 & 0 & 0 & $1(1)$ & 0 & 0 & 0 & 0 & $1(1)$ \\
\hline 3 Lathrobium sp. & $1(1)$ & $1(1)$ & 0 & $2(1)$ & 0 & 0 & 0 & $1(1)$ & $5(4)$ \\
\hline 6 Tachinus sp. & $1(1)$ & $1(1)$ & $9(5)$ & 0 & $1(1)$ & 0 & $1(0)$ & 0 & $13(8)$ \\
\hline $6 T$. brevipennis Sahlb. & $3(2)$ & 0 & 0 & 0 & 0 & $2(2)$ & $1(1)$ & 0 & $6(5)$ \\
\hline $6 T$. apterus type & $4(4)$ & 0 & 0 & 0 & 0 & 0 & 0 & 0 & $4(4)$ \\
\hline $6 T$. brevipennis-apterus grp. & $5(0)$ & 0 & 0 & $2(1)$ & 0 & $3(0)$ & $1(0)$ & 0 & $11(1)$ \\
\hline 2 Tachyporus sp. & 0 & 0 & 0 & $1(1)$ & 0 & 0 & 0 & 0 & $1(1)$ \\
\hline 3 Gymnusa sp. & 0 & 0 & 0 & $1(1)$ & 0 & 0 & 0 & 0 & $1(1)$ \\
\hline $\begin{array}{l}\text { ? Aleocharinae, undet. } \\
\text { Silphidae }\end{array}$ & $9(4)$ & $1(1)$ & $5(2)$ & $31(11)$ & $12(8)$ & $37(17)$ & $55(18)$ & $7(3)$ & $157(64)$ \\
\hline $\begin{array}{l}7 \text { Silpha sp. } \\
\text { Leiodidae }\end{array}$ & 0 & 0 & $2(1)$ & 0 & 0 & 0 & 0 & 0 & $2(1)$ \\
\hline 4 Agathidium sp. & 0 & 0 & $2(1)$ & $1(1)$ & 0 & 0 & 0 & 0 & $3(2)$ \\
\hline $\begin{array}{l}5 \text { Scydmaenidae, undet. } \\
\text { Scarabaeidae }\end{array}$ & 0 & 0 & $1(1)$ & 0 & 0 & 0 & 0 & 0 & $1(1)$ \\
\hline 2 Aegialia sp. & 0 & 0 & $1(1)$ & 0 & 0 & 0 & 0 & 0 & $1(1)$ \\
\hline $\begin{array}{l}8 \text { Aphodius sp. } \\
\text { Byrrhidae }\end{array}$ & $6(3)$ & $6(4)$ & $3(2)$ & 0 & 0 & $1(1)$ & $1(1)$ & 0 & $17(11)$ \\
\hline 2 Simplocaria & 0 & 0 & $17(8)$ & 0 & 0 & 0 & 0 & 0 & $17(8)$ \\
\hline 2 Morychus sp. & $9(4)$ & $10(4)$ & $38(13)$ & 0 & 0 & 0 & 0 & 0 & $57(21)$ \\
\hline 2 cf. Morychus sp. & 0 & 0 & 0 & 0 & 0 & 0 & 0 & $1(1)$ & $1(1)$ \\
\hline 4 Coccinellidae, undet. & 0 & 0 & 0 & 0 & 0 & 0 & $1(1)$ & 0 & $1(1)$ \\
\hline 4 Lathridiidae, undet. & $2(2)$ & 0 & 0 & 0 & 0 & $4(2)$ & 0 & $1(1)$ & $7(5)$ \\
\hline 4 Chrysomelidae, undet. & 0 & 0 & 0 & 0 & 0 & 0 & $1(0)$ & 0 & $1(0)$ \\
\hline 3 Donacia sp. & $1(1)$ & 0 & $2(1)$ & 0 & 0 & 0 & 0 & 0 & $3(2)$ \\
\hline 4 Chrysolina sp. & $3(1)$ & $2(1)$ & 0 & 0 & 0 & $2(1)$ & $1(1)$ & $1(1)$ & $9(5)$ \\
\hline 4 Curculionidae, undet. & 0 & $2(1)$ & $13(0)$ & 0 & 0 & 0 & $1(0)$ & 0 & $16(1)$ \\
\hline 4 Leptopiinae, undet. & 0 & $1(1)$ & 0 & 0 & 0 & 0 & 0 & 0 & $1(1)$ \\
\hline 4 Hypera sp. & $2(1)$ & 0 & 0 & 0 & 0 & 0 & 0 & 0 & $2(1)$ \\
\hline 2 Lepidophorus lineaticollis Kby. & $230(97)$ & $423(132)$ & $168(89)$ & 0 & 0 & $5(4)$ & $5(2)$ & $2(1)$ & $833(325)$ \\
\hline 2 L. ?lineaticollis Kby. & 0 & 0 & $117(2)$ & 0 & 0 & 0 & 0 & 0 & $117(2)$ \\
\hline 2 Vitavitus thulius Kiss. & 0 & 0 & $16(6)$ & 0 & 0 & 0 & 0 & 0 & $16(6)$ \\
\hline 2 V. ?thulius Kiss. & 0 & 0 & $1(1)$ & 0 & 0 & 0 & 0 & 0 & $1(1)$ \\
\hline 4 Lepyrus sp. & 0 & $3(1)$ & 7 (2) & 0 & 0 & 0 & 0 & 0 & $10(3)$ \\
\hline 4 Lepyrus? & 0 & 0 & $3(0)$ & 0 & 0 & 0 & 0 & 0 & $3(0)$ \\
\hline 2 Cleoninae, Cleonis? & 0 & $1(1)$ & $11(3)$ & 0 & 0 & 0 & 0 & 0 & $12\langle 4\rangle$ \\
\hline 4 Hylobius sp. & 0 & 0 & $3(1)$ & 0 & 0 & 0 & 0 & 0 & $3(1)$ \\
\hline 5 Pissodes sp. & 0 & 0 & $1(1)$ & 0 & 0 & 0 & 0 & 0 & $1(1)$ \\
\hline 4 Grypus sp. & 0 & 0 & $1(1)$ & 0 & 0 & 0 & 0 & 0 & $1(1)$ \\
\hline 4 Notaris sp. & 0 & 0 & $7(2)$ & 0 & 0 & 0 & 0 & 0 & $7(2)$ \\
\hline 4 Apion sp. & 0 & 0 & $1(1)$ & 0 & 0 & 0 & 0 & 0 & $1(1)$ \\
\hline 4 Apion? & 0 & 0 & $2(2)$ & 0 & 0 & 0 & 0 & 0 & $2(2)$ \\
\hline
\end{tabular}




\begin{tabular}{|c|c|c|c|c|c|c|c|c|c|}
\hline Samples: & $77-51$ & $78-64$ & $78-91$ & $78-1$ & $78-48$ & $78-49$ & $78-50$ & $78-63$ & Totals \\
\hline $\begin{array}{l}4 \text { Rhynchaenus sp. } \\
4 \text { Rhynchaenus? } \\
5 \text { Scolytidae, undet. } \\
5 \text { Carphoborus? }\end{array}$ & $\begin{array}{l}1(1) \\
0 \\
0 \\
0\end{array}$ & $\begin{array}{l}0 \\
0 \\
0 \\
0 \\
\end{array}$ & $\begin{array}{r}12(5) \\
2(0) \\
2(0) \\
1(1) \\
\end{array}$ & $\begin{array}{l}0 \\
0 \\
0 \\
0 \\
\end{array}$ & $\begin{array}{r}0 \\
0 \\
0 \\
0 \\
\end{array}$ & $\begin{array}{l}0 \\
0 \\
0 \\
0 \\
\end{array}$ & $\begin{array}{l}0 \\
0 \\
0 \\
0 \\
\end{array}$ & $\begin{array}{l}0 \\
0 \\
0 \\
0 \\
\end{array}$ & $\begin{array}{r}13(6) \\
2(0) \\
2(0) \\
1(1) \\
\end{array}$ \\
\hline Total Coleoptera & 389 (191) & $530(192)$ & $1015(379)$ & $99(38)$ & $68(29)$ & $187(71)$ & $166(60)$ & $59(26)$ & $2513(986)$ \\
\hline $\begin{array}{l}\text { Lepidoptera, undet. } \\
\text { Diptera, undet. } \\
\text { Hymenoptera, undet. } \\
\text { Ichneumonoidea, undet. } \\
\text { Ichneumonidae, undet. } \\
\text { cf. Cynipidae, undet. } \\
\text { cf. Dryinidae, undet. }\end{array}$ & $\begin{array}{l}+ \\
+ \\
+\end{array}$ & $\begin{array}{l}+ \\
+\end{array}$ & $\begin{array}{l}+ \\
+ \\
+\end{array}$ & $\begin{array}{l}+ \\
+ \\
+\end{array}$ & & + & $\begin{array}{l}+ \\
+ \\
+\end{array}$ & + & \\
\hline $\begin{array}{l}\text { ARACHNIDA } \\
\text { Acari, undet. }\end{array}$ & & & & & & & + & + & \\
\hline $\begin{array}{l}\text { CRUSTACEA } \\
\text { Cladocera, undet. } \\
\text { Daphnia sp. }\end{array}$ & + & & & & & & & + & \\
\hline $\begin{array}{l}\text { BRYOZOA } \\
\text { Crisatella mucedo Cuvier }\end{array}$ & & & + & & & & & & \\
\hline
\end{tabular}

\footnotetext{
* Frequencies represent numbers of identified specimens (NISP) with minimum numbers of individuals (MNI) in parentheses. EG = ecological groups (see MATTHEWS, 1983: 1, Cryobius; 2, Lepidophorus-Morychus; 3, Hygrophilus; 4, Phytophagous; 5 , Formicid; 6 , Tachinus; 7 , Silphid; 8 . Aphodius; ? = unassigned. + = present; undet. = undetermined.

** Eucnecosum sp. $=$ Arpedium sp. of previous reports on northern insects.
}

becomes possible to distinguish fossil heads of $H$. splendidus from related species, one might find that our total underrepresents the actual number of Helophorus individuals, but we feel this type of error is preferable to an inflated figure. Similar reasoning was used to adjust the $\mathrm{MNI}$ values for other taxa in Table 1.

Chi-squared tests were run with a computer programme written in BASIC and offering the option of incorporating the Yates correction for continuity. Significant differences were defined as those for which the probability that chi-squared will be exceeded is less than $5 \%$. In order to achieve suitable sample size, two peat ball samples $(78-48,78-50)$ were combined since their field relationship indicates that they come from the same peat (as does 78-49 which contained a large enough assemblage for separate analysis). Chi-squared tests were run on the distributions of both anatomical parts and ecological groupings (see below).

\section{TAPHONOMIC CONSIDERATIONS}

Taphonomy is the science concerned with the changes that occur to organisms as they pass from being members of the biosphere to become incorporated in sediments or other media (see OLSON, 1980, for a discussion of the history and trends in taphonomy). The objective of a taphonomic study is to document as completely as possible all the steps between those two end-points.
Three types of taphonomic observations were made for this paper. The first of these deals with chemical degradation. The excellent preservation of most Quaternary insect fossils shows that insect cuticle is remarkably resistant to the chemical milieu existing in most soil environments. In northern areas, cold soil temperatures, permafrost and low $\mathrm{pH}$ further buffer insect fossils from chemical decay. Nevertheless, some insect fossils do exhibit features or flaws that are probably chemical or microbiological in origin. The less sclerotized beetles (e.g., teneral specimens) or those with clear spots (maculae) or regions on the elytra and pronota appear to be most susceptable to such degradation. Fossils preserved in sands or other well drained sediments often possess punctures which are probably the result of some type of chemical activity (LINDROTH, 1948), and in some cases elytra are so decimated by progressive enlargement of the punctures that they become little more than a fragile chitonous lattice. Of the samples discussed here, only 78-91, in which the fossils display a high frequency of postmortem pitting, shows much evidence of chemical or microbial attack. Significantly, that sample comes from sandy alluvium that was probably thawed for much of late Pleistocene time.

The chief agency of destruction that has acted on the fossils discussed below is physical: the breakage and disarticulation that occurs during fluvial transport or the slow but disruptive movements associated with freeze- 
thaw cycles. Hence, our second type of taphonomic observation concerns the frequency of articulated or partially articulated specimens. By this we mean specimens that have the elytral halves still joined at the suture, elytra still attached to abdomens, pronota to the ventral parts of the prothorax, heads to prothoraces, or even those rare fossils (usually found in peat) that lack only parts of the antennae and legs.

Fossils were not articulated in three of the samples (78-49, 78-63, 78-91), and in two others $(77-51,78-64)$, the only articulated fossils were pronota/heads and right/left elytra halves of the weevil, Lepidophorus lineaticollis. Since L. lineaticollis is flightless, its elytral halves are fused at the suture, so articulated elytra are not by themselves of great significance. In some samples (11 fossils in 78-64), however, pronota and heads or various parts of the abdomen were also joined and a few of the fossil heads retained antennal fragments. Other $L$. lineaticollis fragments still possessed some of the delicate scales that clothe the beetle in life. In northern North America, Lepidophorus lineaticollis is one of the most common beetles of sandy floodplains, and its fossils often dominate arthropod assemblages from alluvial samples. Nevertheless, it is rare to find specimens as well preserved as in samples 77-51 and 78-64. Obviously the fossils of $L$. lineaticollis in those two samples have not been transported far (if at all) prior to deposition, meaning that $L$. lineaticollis was probably a member of the proximal arthropod community at the site of deposition.

All articulated specimens in the remaining samples refer to taxa that do not normally have fused elements when living. In 78-1, two Ochthebius fossils consist of joined heads and pronota. In 78-48, there occurred one articulated pronotum and head of Hydroporus ; in 78-50, a similar style of preservation is typical of some Helo- phorus fossils. We believe that articulation represents minimal post-mortem transportation. An assemblage with a high frequency of articulated specimens would be autochthonous, whereas one in which only a few specimens were articulated would probably be allochthonous, with the articulated specimens representing taxa that lived at or near the site of deposition.

A third taphonomic observation concerns the relative frequency of anatomical elements in an assemblage. Shape and size influence sorting of sedimentary particles, and there is no reason to expect that the situation should be any different for fluvially transported insect remains. An additional factor with insect fossils is that some have shapes that are suitable for trapping an air bubble, making them extremely buoyant. We should expect, therefore, that in an autochthonous assemblage the proportion of various anatomical elements will match the ratio for a living insect. For beetles this means twice as many elytra as heads or pronota. On the other hand, the frequencies of the various anatomical elements in an allochthonous assemblage, such as might come from alluvial sediments, may deviate from the live insect ratio. In practice, the ratio for fossils never matches exactly the expected one because all assemblages are allochthonous to some degree. For purposes of the following discussion, we assume that in autochthonous or nearly autochthonous assemblages the relative frequencies of anatomical parts will not deviate significantly from the expected (i.e., living) ratio.

There are several ways to test this assumption. One of the simplest is a chi-squared test on frequency of left vs. right elytra. In none of the samples do the frequencies depart significantly from expected. A more complex comparison, illustrated in Table II, is a chisquared test of the distribution of four anatomical

TABLE ॥

Distribution of beetle anatomical parts in samples from Old Crow River Loc. 15, northern Yukon Territory*

\begin{tabular}{|c|c|c|c|c|c|c|c|}
\hline Observed element frequencies & $77-51$ & $78-64$ & $78-91$ & $78-1$ & $78-48 \& 50$ & $78-49$ & $78-63$ \\
\hline Left elytron & 38 & 132 & 466.5 & 34 & 61 & 42.5 & 14.5 \\
\hline Right elytron & 37 & 116 & 432.5 & 26 & 57 & 45.5 & 15.5 \\
\hline Pronotum & 146 & 164 & 83 & 18 & 72 & 54 & 17 \\
\hline Head & 168 & 118 & 33 & 21 & 43 & 45 & 12 \\
\hline Total & 389 & 530 & 1015 & 99 & 234 & 187 & 59 \\
\hline \multicolumn{8}{|l|}{ Expected element frequencies: } \\
\hline Total/4 & 97.25 & 132.5 & 253.75 & 24.75 & 58.5 & 46.75 & 14.75 \\
\hline Chi-squared: & 146.9 & 11.1 & 611.2 & 5.1 & 7.4 & 1.6 & 0.6 \\
\hline Probability $(P)$ : & $<0.001$ & $<0.02$ & $<0.001$ & $>0.10$ & $>0.05$ & $>0.80$ & $>0.80$ \\
\hline Contingency coefficient: & 0.524 & 0.143 & 0.613 & 0.221 & 0.175 & 0.092 & 0.100 \\
\hline Decision $\mathrm{H}$ : & Rejected & Rejected & Rejected & Not rejected & Not rejected & Not rejected & Not rejected \\
\hline
\end{tabular}

\footnotetext{
* Null hypothesis $(\mathrm{H})$ : that the distribution of anatomical parts does not differ significantly from that of Coleopteran anatomy; in all tests there are three degrees of freedom; $P$ is stated as the probability that chi-squared will be exceeded. Elytral fragments are equally divided between left and right sides.
} 
parts: right and left elytra, pronotum, and head. It provides results that are entirely consistent with our other considerations regarding these samples. For example, stratigraphy and sample provenance suggest that the organics of 77-51, 78-64, and 78-91 are allochthonous, having been deposited in fluvial environments. As indicated in Table II, the null hypotheses that the distribution of anatomical parts does not differ significantly from that of living beetles is rejected for each of these samples. On the other hand, the insects from samples $78-1,78-48$ \& 50 , and 78-49 (pieces of peat that appeared to have been transported en bloc) and from 78-63 (forest floor litter) are believed on stratigraphic and textural grounds to be autochthonous; appropriately their chi-squared tests fail to reject the null hypothesis.

One peculiarity of the allochthonous assemblages in Table II is difficult to explain. The two assemblages from Disconformity A (77-51, 78-64) exhibit a statistically significant excess of pronota and heads compared to elytra while the assemblage from 78-91 displays an excess of elytra. It is possible that these differences are due to the relative abundance of Lepidophorus fossils in the disconformity samples, because fossils of this taxon seem to possess unusual properties that could influence their taphonomic histories. The pronota and heads of $L$. lineaticollis are much more likely to contain air bubbles when placed in water than are heads and pronota of other beetles; hence the heads and pronota of waterborne Lepidophorus are not likely to be deposited at the same site as elytra. We have seen fossil assemblages that display the opposite condition from the disconformity samples, that is they are dominated by Lepidophorus elytra but contain hardly any heads or pronota. Highly convex Lepidophorus elytra, especially those that are sutured, may be tightly packed with sediment, and the resultant increase in density will cause them to be deposited sooner than other anatomical elements. Obviously then, some beetles, and particularly Lepidophorus, are subject to special taphonomic biases during transportation. This phenomenon needs further study, perhaps through flume experiments.

\section{PALEOECOLOGY}

Some of the identifications listed in this paper are preliminary and may be subject to future refinement. For many others the genus is now and will remain the most precise level of identification. The inclusion in a fossil assemblage of specimens identified to different taxonomic levels complicates interpretation. One assemblage with well preserved fossils, many of which are specifically identified, may appear quite different from another one which is less diverse or which has fossils less well preserved; yet both could represent similar biotopes and the same regional environment. To alleviate this kind of problem and to facilitate assemblage comparisons, we have sorted the assemblages into groups that reflect either the broad ecological implications of the fossils or certain unexplained peculiarities of northern assemblages. The ecological group to which a fossil belongs is indicated in Table I by a number that corresponds to the group name (see Table I footnote). The groups used here are those used and discussed by MATTHEWS (1983, see also HUGHES et al., 1981: Appendix B).

The use of broadly defined ecological groups reduces the long list of taxa (Table I) to a more manageable number of categories (Table III) with which assemblages can be compared by means of statistical tests. We elected to use chi-squared tests of pairs of assemblages with the null hypothesis that both samples of the pair were drawn from the same population. Chisquared tests could not have been run on the ungrouped data in Table I, because expected frequencies would have been too low to satisfy the test requirements (see SIEGEL, 1956: 110). Even when the data are

TABLE III

Numbers of identified specimens (NISP) and, in parentheses, minimum numbers of individuals (MNI) per ecological group as defined by MATTHEWS

(1983, see also Fig. 2)

\begin{tabular}{|c|c|c|c|c|c|c|c|c|}
\hline Ecological Group & $77-51$ & $78-64$ & $78-91$ & $78-1$ & $78-48 \& 50$ & $78-49$ & $78-63$ & Totals \\
\hline 1. Cryobius group & $37(27)$ & $33(20)$ & $362(169)$ & $8(4)$ & 0 & $2(1)$ & $1(1)$ & $443(222)$ \\
\hline 2. Lepidophorus-Morychus group & $276(125)$ & $457(152)$ & $455(164)$ & $6(3)$ & $12(8)$ & $10(7)$ & $3(2)$ & $1219(461)$ \\
\hline 3. Hygrophilous group & $33(20)$ & $20(10)$ & $54(17)$ & $47(18)$ & $143(50)$ & $125(40)$ & $46(18)$ & $468(173)$ \\
\hline 4. Phytophagous group & $8(5)$ & $8(4)$ & $53(15)$ & $1(1)$ & $4(2)$ & $6(3)$ & $2(2)$ & $82(32)$ \\
\hline 5. Formicid (Scolytid) group & 0 & 0 & $5(3)$ & 0 & 0 & 0 & 0 & $5(3)$ \\
\hline 6. Tachinus group & $13(7)$ & $1(1)$ & $9(5)$ & $2(1)$ & $4(2)$ & $5(2)$ & 0 & $34(18)$ \\
\hline 7. Silphid group & 0 & 0 & $2(1)$ & 0 & 0 & 0 & 0 & $2(1)$ \\
\hline 8. Aphodius group & $6(3)$ & $6(4)$ & $3(2)$ & 0 & $1(1)$ & $1(1)$ & 0 & $17(11)$ \\
\hline Sum & $373(187)$ & $525(191)$ & $943(376)$ & $64(27)$ & $164(63)$ & $149(54)$ & $52(23)$ & $2270(921)$ \\
\hline ?. Unassigned forms & $16(4)$ & $5(1)$ & $72(3)$ & $35(11)$ & $70(26)$ & $38(17)$ & $7(3)$ & $243(65)$ \\
\hline Totals & $389(191)$ & $530(192)$ & 1015 (379) & $99(38)$ & $234(89)$ & $187(71)$ & $59(26)$ & $2513(986)$ \\
\hline
\end{tabular}


grouped as in Table III, samples $78-1$ and $78-63$ fail to meet the requirements, and $78-48$ and $78-50$ must be combined to achieve expected frequencies of suitable size.

Pairs of the other samples were tested first on the basis of the number of identified specimens (NISP) in each ecological group. In order to meet the test requirements, the following combinations of groups were employed: $1+6,2,3,4+5+7+8$. All but one pair depart significantly from expected NISP frequencies, causing a rejection of the null hypothesis. The exception is the pair of peat ball samples, $78-48$ \& 50 and 78-49 $(\mathrm{P}>$ $0.50)$; the stratigraphic context of these samples suggests they have a common origin.

Since some of the samples contain larger numbers of elytral fragments than others, we were concerned that the apparent differences based on NISP might reflect variations in the state of preservation of fossils rather than in paleoecological variables. For example, approximately $25 \%$ of the group 2 NISP in sample $78-91$ consists of elytral fragments whereas none of the group 2 specimens in sample $77-51$ is fragmentary. In order to eliminate such effects we used minimum numbers of individuals (MNI) in a second series of chi-squared tests. It is noteworthy that the rank order of groups 1 and 2 is reversed for sample 78-91 when $\mathrm{MNI}$ is used, but no other changes in rank order are introduced by $\mathrm{MNI}$ (Table III). Furthermore, the results of the chi-squared tests using $\mathrm{MNI}$ agree with those that were based on NISP : all pairs tested depart significantly from expected frequencies except for the pair of peat ball samples (78-48 \& 50 and 78-49; $P>0.70)$. Therefore, we conclude that comparisons of assemblages using the relative abundance of $\mathrm{MNI}$ within the ecological groups are meaningful with respect to paleoecological variables.

The chi-squared tests were based only on the eight groups included in the "sum" in Table III. The sum excludes insects that could not be assigned to a group. One unassigned individual in $78-91$ is an unidentified rove beetle (Staphylinidae), and all others in Table III can be referred to the sub-family Aleocharinae (Staphylinidae). This sub-family is badly in need of taxonomic revision; most of its members cannot be identified even to genus in fossil samples, and the ecological placement of fossils identified only to this sub-family is vague.

All of the taxa reported in Table I occur or are expected to occur in the Old Crow area today, but some are quite rare. For example, Morychus which is very abundant in some of the assemblages is rarely collected today. The weevil Vitavitus thulius is known from only a few widely scattered localities in North America, and until the 1981 field season had not been found living in the Yukon Territory. In 1981, it was collected with Morychus and Lepidophorus lineaticollis at a fellfield site on a dolomite ridge near Old Crow. This discovery suggests that plant communities with discontinuous cover may have existed in the lowlands at the time of Disconformity A, but they cannot have been exact analogues of the fell-field where these beetles are found today. The lowlands of the past, like those of today, had substrates of alluvium whereas the modern fell-field is on dolomitic bedrock. Nonetheless, the rarity of these beetles in the modern lowlands suggests that lowlands were formerly quite different in some respects.

Sample 78-91 stands apart from all the others in terms of its group composition. Groups 1 and 2 are co-dominant, and Group 3, so well represented in the autochthonous samples, is but a small fraction of the total (see Fig. 2). The taxonomic composition of 78-91
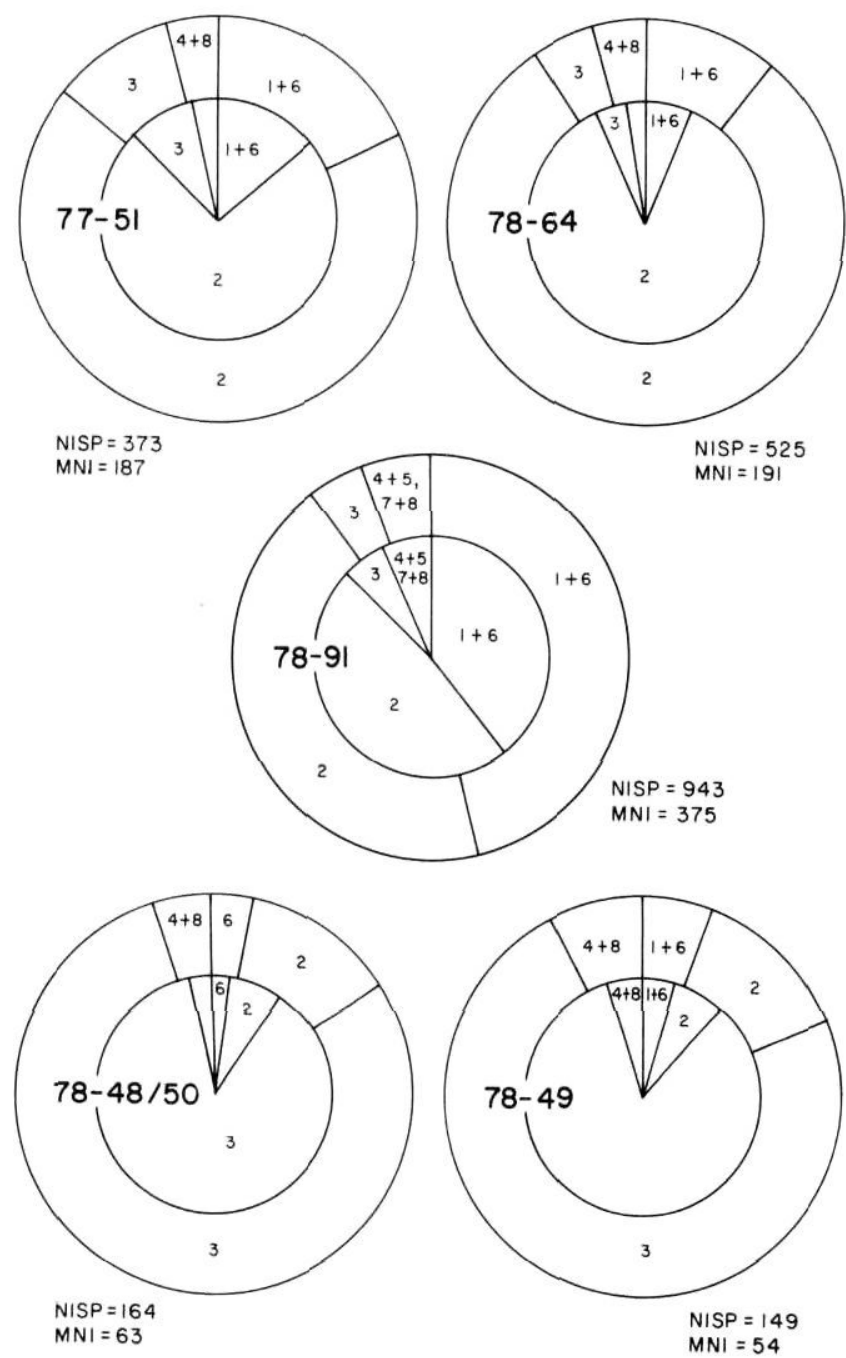

FIGURE 2. Pie diagrams of five of the fossil insect assemblages from CRH-15. The inner circle is based on NISP and the outer on MNI (see Table III). Numbers within the circles refer to ecological groups as shown in Table III (see also MATTHEWS, 1983).

Diagrammes de cinq des associations d'insectes fossiles du site $\mathrm{CRH}-15$. Le cercle intérieur représente le nombre de spécimens identifiés (NISP) et le cercle extérieur, les nombres minimaux d'individus (MNI) par groupe écologique (voir le tableau (II). Les chiffres qui apparaissent dans les cercles se rapportent aux groupes écologiques indiqués au tableau III (voir aussi MATTHEWS, 1983, à paraître). 
also sets it apart. Micralymma, Morychus and Amara are much less abundant than in the other samples (Table I), and $78-91$ is the only sample that contains fossils of Vitavitus thulius, Grypus, Notaris, Diacheila polita, Opisthius richardsoni and bark beetles (Scolytidae). By these features 78-91 resembles insect assemblages from a similar stratigraphic position at other Old Crow Basin exposures (MATTHEWS, 1975). When insects, as well as pollen, plant macrofossils and vertebrates, are considered (LICHTI-FEDEROVICH, 1973; MATTHEWS, 1975; HARINGTON, 1977), the environment at the time of deposition of the sediments above those of the lower lake appears to have been different from any that followed it, including the warm interval associated with Disconformity $\mathrm{A}$ and the present.

\section{DISCUSSION}

In this paper we have attempted to examine fossil insect data in a different way, with the hope of improving the meaning of sample comparisons. The need for such an approach is, in part, dictated by the northern fauna itself. This fauna is still poorly known for many coleopteran groups, and thus those of us engaged in the study of fossils will continue to produce taxonomic lists that are uneven with respect to the taxonomic level of the determinations. An equally important factor in our decision to take this approach, however, is the realization that the assemblages of fossils are sometimes overprinted with strong taphonomic biases. Although such problems may be serious only for alluvial sediments and particular taxa, e.g., Lepidophorus lineaticollis, we believe that taphonomic histories are of broader significance. Such histories must be considered in the analysis of any fossil insect assemblage, and appropriate measures must be taken to account for their influences. First, however, we need to learn more about how insects become fossils. One way is through extensive study of the content of insect fragments in modern river alluvium and modern thaw lake sediments. Such studies have begun, and already they are revealing some surprises concerning the transportation and deposition of insect fragments. In a sense we are using modern analogues the way that palynologists use surface pollen samples, though with the understanding that modern insect assemblages, like their fossil counterparts, always represent the local rather than regional environments.

The importance of local influences, indeed of microenvironment, is well illustrated in Figure 2. Of the samples from the disconformity, two are dominated by inhabitants of dry, scantily vegetated biotopes, and the others are dominated by beetles that live in ponds or on the wet shorelines of bogs. The dry site fossils come from sediments that enclosed the peat balls in which the bog and lake types occur, and field data indicate that the two types of samples were deposited penecontemporaneously. Together they provide a broader picture of the environment at the time of formation of the disconformity than any single sample could. The contrasts exhibited by these samples provide a clear warning of the potential errors that may arise if the stratigraphic context and taphonomic history of fossil insect samples are not given due consideration. One may imagine, for example, the potential for error if samples are collected from small, poorly exposed sections. Allochthonous masses of peat do not always occur in the form of small pods, as they did in this instance. The sandy shorelines of the present Old Crow River are sometimes littered with peat balls that are probably at least several thousand years older than their host sediments. Some in fact probably originate from the late Pleistocene peats slumping and sliding into the river. One of us (JVM) has even observed large Miocene age peat balls within Pleistocene sands at an exposure on the lower Porcupine River in Alaska. The discrepancies between the fauna and flora of these peats and their host sediments would indeed be spectacular, although at the same time immediately obvious. Peat balls that are closer in age to their host sediments pose more serious interpretive problems, because the faunal distinctions are likely to be more subtle.

Along the modern rivers of the northern Yukon, one is likely to see tablets of peat, meters in length, that have caved from some upstream site, floated downriver and then become grounded in shallow water. When buried and later exhumed, these organic deposits hardly deserve the epithet "peat ball." We have observed such allochthonous peat tablets in sections, but they have been recognized as such only after close examination of the lateral extent of the horizon and the nature of its contacts with underlying and overlying sediments.

From a larger perspective, we believe that the best aid in the interpretation of fossil insects, or indeed any particular kind of paleoenvironmental evidence, is the integration of the widest possible variety of fossil data. Although this paper has focussed exclusively on the insects, and in particular on the beetles, our reconstruction of ancient environments in the northern Yukon will eventually incorporate data from all other available sources: pollen, plant macrofossils, mollusks, vertebrates, and detailed stratigraphic observations. Such a synthesis offers the best opportunity to rationalize and explain associations that might seem contradictory when viewed from the perspective of a single data set. Furthermore the integration of taphonomic histories constructed separately for each kind of fossil evidence should provide a framework for understanding both local and regional patterns on the basis of samples taken from several localities in Old Crow Basin.

\section{ACKNOWLEDGEMENTS}

Thanks are extended to Allan Ashworth and W. Blake, Jr. for their critical reviews and to D.W. Laverie for drafting the figures. This paper is contribution number 72 of the Yukon Refugium Project. An earlier version of this paper was delivered at the Third North 
American Paleontological Convention, Montréal, Québec, 1982.

\section{REFERENCES CITED}

BOBROWSKY, P.T. (1982): The quantitative and qualitative significance of fossil and subfossil gastropod remains in archaeology, MA Thesis, Simon Fraser University, Burnaby, $294 \mathrm{p}$.

COOPE, G.R. (1978): Constancy of insect species versus in constancy of Quaternary environments, in Diversity of Insect Faunas, edited by L.A. Mount and N. Waloff, Symposia Royal Entomological Society of London, 9: 176-187.

- (1979): Coleoptera analysis, in Palaeohydrological changes in the temperate zone in the last 15000 years: subproject B: Lake and Mire environments, vol. 2. specific methods, edited by B.E. Berglund, p. 315-328, Lund.

CUMBAA, S. L., MCALLISTER, D.E. and MORLAN, R.E. (1981): Late Pleistocene fish fossils of Coregonus, Stenodus, Thymallus, Catostomus, Lota, and Cottus from the Old Crow basin, northern Yukon, Canada, Canadian Journal of Earth Sciences, 18: 1740-1754.

FIELLER, N.R.J. and TURNER, A. (1982): Number estimation in vertebrate samples, Journal of Archaeological Science, $9(1)$ : 49-62.

HARINGTON, C.R. (1977): Pleistocene mammals of the Yukon Territory, PhD dissertation, University of Alberta, Edmonton $1060 \mathrm{p}$.

HUGHES, O.L. (1972): Surficial geology of northern Yukon Territory and northwestern District of Mackenzie, Northwest Territories, Geological Survey of Canada Paper 69-36, 11 p.

HUGHES, O.L., HARINGTON, C.R., JANSSENS, J.A., MATTHEWS, J.V., Jr., MORLAN, R.E., RUTTER, N.W., and SCHWEGER, C.E. (1981): Upper Pleistocene stratigraphy, paleoecology, and archaeology of the northern Yukon interior, eastern Beringia, 1. Bonnet Plume Basin, Arctic, 34(1) : 329-365.

JANSSENS, J.A.P. (1981): Subfossil bryophytes in eastern Beringia: their paleoenvironmental and phytogeographic significance, $\mathrm{PhD}$ dissertation, University of Alberta, $163 \mathrm{p}$.

LICHTI-FEDEROVICH, S. (1973): Palynology of six sections of late Quaternary sediments from the Old Crow River, Yukon Territory, Canadian Journal of Botany, 51: 553-64.
LINDROTH, C.H. (1948): Interglacial insect remains from Sweden, Sveriges Geologiska Undersokning, Ser. C., 492 : 1-29.

MATTHEWS, J.V., Jr. (1975): Insects and plant macrofossils from two Quaternary exposures in the Old Crow-Porcupine region, Yukon Territory, Canada, Arctic and Alpine Research, 7(3) : 249-259.

(1980) : Tertiary land bridges and their climate: backdrop for development of the present Canadian fauna, Canadian Entomologist, 112: 1089-1103.

(1982): East Beringia during late Wisconsinan time: a review of the biotic evidence, in Paleoecology of Beringia, edited by D. M. Hopkins, J.V. Matthews, Jr., C.E. Schweger, and S. B. Young, p. 127-150, New York, Academic Press.

(1983): A method for comparison of northern fossil insect assemblages, Géographie physique et Quaternaire, vol. 37 , No. 3 (to be published).

MORLAN, R.E. (1980): Taphonomy and Archaeology in the Upper Pleistocene of northern Yukon Territory: a glimpse of the peopling of the New World, Ottawa, National Museum of Man (Mercury Series: Archaeological Survey of Canada Paper no. 94).

- (n.d.a.): Pleistocene archaeology in Old Crow Basin: a critical reappraisal, in New Evidence for the Pleistocene Peopling of the Americas, edited by A. L. Bryan, in press, Orono: Center for the Study of Early Man, University of Maine.

(n.d.b.): Quaternary microtine rodents from northern Yukon Territory, Submitted to Carnegie Museum of Natural History.

MORLAN, R. E. and MATTHEWS, J. V., Jr. (1978) : New dates for early man, GEOS Winter, 1978: 2-5.

OLSON, E. C. (1980): Taphonomy: its history and role in community evolution, in Fossils in the Making, edited by A.K. Behrensmeyer and A.P. Hill, p. 5-19, Chicago, University of Chicago Press.

SIEGEL, S. (1956): Nonparametric statistics for the behavioral sciences, New York, McGraw-Hill.

TURNER, A. (1980): Minimum number estimation offers minimal insight in faunal analysis, Ossa, $7: 199-201$.

WESTGATE, J.A., HAMILTON, T.D. and GORTON, M.P. (1983): Old Crow tephra: a new Late Pleistocene stratigraphic marker across Alaska and the Yukon Territory, Quaternary Research, 19: 38-54. 